\title{
Writing National Identity on the Wall: the Geração Foun, Street Art and Language Choices in Timor-Leste
}

Catherine Elizabeth Arthur ${ }^{1}$

Queen's University Belfast, School of Modern Languages, UK

\begin{abstract}
The generational divide that has emerged in Timor-Leste since its return to independence in 2002 is perhaps one of the most significant challenges to the ongoing nation-building project. ${ }^{2}$ The consecutive occupations of Timor-Leste by Portugal and Indonesia have left distinct cultural-linguistic heritages for the respective generations. As a result of its cultural and linguistic association with the most recent foreign occupier, members of the Geração Foun (the 'new generation') have experienced cultural exclusion and significant under-representation in the new nation-state. This article explores the ways in which a group of artists from this younger generation has utilised street art as a public medium of expression to identify with, and simultaneously critique, the dominant culture of the post-independence state established by the older generation. The artists identify as members of the Geração Foun and their work highlights and represents grievances that have been expressed by many as a result of the generational divide in the post-independence state. These articulations are expounded by the language choices made by the street artists in their work.
\end{abstract}

Keywords: Timor-Leste, Geração Foun, Centro Arte Moris, street art, national identity, nation-building

The recent history of Timor-Leste has been dominated by foreign occupation, with a brutal annexation by Indonesia that lasted for almost a quarter of a century after 450 years of Portuguese colonialism. Since the official return to self-determination in 2002, the national unity that was fostered under the resistance to the Indonesian occupation was somewhat weakened by the absence of a common enemy, and divisions within the national community began to emerge (Kingsbury 2010: 41). One of the most significant social divides has stemmed from the two distinct cultural-linguistic heritages that are the legacies of the consecutive occupations. These differences have culminated in the so-called 'generation gap' which presents one of

1 Email: carthur02@qub.ac.uk

2 I would like to express special thanks to Professor Bill Rolston for his invaluable suggestions and help with my work on street art. 
the greatest challenges to the on-going nation-building project. As a result, debate over official language policies, national historical narratives and, in particular, national identity continue to be contentious in the East Timorese state which is largely seen to have privileged the older generation's Lusophone heritage at the expense of the marginalised Geração Foun (the "new generation"). ${ }^{3}$

As a result of their significant under-representation within the national community in the early years of independence, some members of the Geração Foun have turned to street art as a means of expressing and identifying themselves publicly. This article analyses the street art produced by artists from the Centro Arte Moris in Dili, which is a non-profit art school in the capital (Arte Moris, http://artemoris.org). The artists who produced the street art examined in this article, and with whom I spoke during my fieldwork in Dili, all identified as members of the Geração Foun in terms of their age and their cultural and educational backgrounds. ${ }^{4}$ While these artists constitute only one group within the Geração Foun located in the capital, their work highlights and reflects some of the main grievances that have been articulated by young people across Timor-Leste, as a result of the generational divide in the post-independence state. As such, the messages and ideas communicated in their street art are the worthy subject of analysis and provide some insight into how these young people have self-identified in a public space in Timor-Leste since 2002.

Marisa Ramos-Gonçalves has outlined three different generational categories in TimorLeste:

the 'generation of 1975,' who lived during the Portuguese colonial period (before 1975), the so-called 'gerasaun foun' who grew up during the Indonesian occupation (1975 to 1999) and, finally, the 'independence generation' who were children in the period of transition from the Indonesian occupation and independence or who were born after the popular ballot (post-1999) (2012a: 4)..$^{5}$

The Geração Foun, according to this definition, are approximately aged over twenty and under fifty years and the average age of the artists at the Centro Arte Moris in Dili is approximately thirty years. ${ }^{6}$ It is precisely because of their education under the Indonesian occupation that this generation of East Timorese has experienced cultural alienation in the post-independence state, in contrast to the members of the "independence generation" who have been educated in the new nation-state. While there are members of Ramos-Gonçalves' independence generation who now participate and engage with street art, the original artists and instigators of painted messages on walls in the post-independence years belong to the Geração Foun. These street artists are now passing on their ideas and techniques to the next generation of younger East Timorese, however, in this article I focus on examples produced by the artists in Dili as members of the Geração Foun who originally identified in this way following the return to in-

3 “A 'geração de 1975', que ocupa actualmente lugares de liderança no Estado, defende um nacionalismo com raizzes lusófonas [The 'generation of 1975,' which currently hold positions of leadership in the State, defends a nationalism with Lusophone roots]" (Ramos Gonçalves 2012: 4). Translation my own.

4 The artists at the Centro Arte Moris in Dili kindly helped me with my fieldwork and contributed greatly to my research on street art in Timor-Leste. All interviews are with artists from this centre.

5 “[ $\mathrm{A}]$ 'geração de 1975' que viveu no periodo colonial Português (antes de 1975), a denominada 'gerasaun foun' que cresceu durante a ocupação Indonésia (1975 a 1999) e, finalmente, a 'gerasaun independensia' que viveu a sua infância no periodo de transição entre ocupação Indonésia e a independência ou que já nasceu após a consulta popular (pós-1999).'Translation my own.

6 This information was gathered during my fieldwork and in personal interviews conducted with the artists in 2012. 
dependence.

Commonly associated with subversive youth in "Western" states, street art can be analysed as a product of youth subcultures that reflects the interpretations of a dominant culture by younger generations. ${ }^{7}$ Street art can provide some of the most telling symbolic representations of popular opinion and identity for young people, allowing insight into the social grievances and ideals of this collective. As Terrance Stocker et al. argue, graffiti is useful as "an aspect of culture, [that] can be used as an unobtrusive measure to reveal patterns of customs and attitudes of a society" (Stocker et al.1972: 356). Given the great amount of street art in Timor-Leste, it is therefore an important tool for understanding the attitudes of an alienated younger generation. Indeed, the importance of graffiti as a means of expressing identities, values and ideas is widely appreciated in Timor-Leste, as one artist articulated:

For Timorese people, graffiti is important. People can see and think about the meaning [...]. Its importance depends on the people, if they stop and see or if they pass. Depends on the feeling of art of each person. In Timor-Leste, many people like art, there are different interpretations but they are all right. Hotu-hotu los (personal interview, Dili 28/07/2012). ${ }^{8}$

However, a critical analysis of street art in Timor-Leste has yet to be fully conducted despite its potential usefulness and particularly in light of the critical socio-political situation of the younger generation. ${ }^{9}$

The focus of analysis here is the public expression of ideas of collective identity construction, national politics and nation-building by artists in Dili, as one group within the Geração Foun. I explore the ways in which street art, as a product of the youth subculture that has emerged since 2002, demonstrates the artists' attempts to challenge and simultaneously identify with the dominant culture in Timor-Leste that has been institutionalised by the older generation. Interestingly, street art in Timor-Leste differs from prevalent notions of graffiti as subversive in nature. In 2006, the East Timorese government, which is comprised of members of the older generation, commissioned a project of street art as a medium of communication with the population. Though much of it is now unofficial and uncommissioned, the street art that has been independently produced since 2006 continues to emit similar messages and themes to those of the commissioned project, as this article will discuss. Regardless of previous collaborations with the government, East Timorese street art continues to be used by the artists to interpret and critique the dominant culture in the post-independence state, echoing the primary grievances of the Geração Foun. One of the most explicit ways in which this tension between identification and differentiation is demonstrated is through the language choices made in creating street art.

Scholarly research has documented that the older generation of East Timorese generally identifies with a Lusophone heritage and privileges Portuguese as an exogenous language in national affairs (for example Taylor-Leech 2009 and 2012: 18; Soares 2009: 97; Leach 2003,

7 Much academic research on graffiti is focused on the United States and Western Europe, hence my reference here to "Western" states. The illicit nature of street art and its associations with criminal activity further the assertion that it is widely considered to be an act of subversion. For example, see Ferrell (1993) and (1995); Gómez (1992: 636-707).

8 Interview conducted in English.

9 It should be noted that Marisa Ramos-Gonçalves has begun to open up the discussion of the importance of street art in Timor-Leste $(2012 ; 2013)$. 
2006 and 2008). In contrast, the younger generation born and educated under the Indonesian occupation are more competent in Bahasa Indonesia and, as a result, are linguistically estranged from their fellow East Timorese. I focus specifically on the ways in which vocabulary from Portuguese and the lingua franca Tetun are used in street art, as they expound this tension inherent in youth identification which must be explored in order to overcome the East Timorese generation gap. Chris Parkinson asserts that the "powerful links to be made between literacy and street art really are celebrating story and engaging East Timorese across generations in fostering a sense of community through art" (Parkinson cited in Storey 2013). While this perspective is perhaps a little premature - tensions arising from the generational divide have not yet been resolved - it attests to the importance of street art as a powerful social tool, and the connections that can be made between it and language in national identity construction.

\section{'Drawing Up' a Definition of a Youth Subculture and Street Art in Timor-Leste}

The popularity of street art has encouraged a greater focus on the subject in academic research and subsequently, an evolving taxonomy for its classification has emerged. Street art has been defined as "any art developed in public spaces," and encompasses free-hand aerosol work, graffiti stencils, murals and sticker art (Gadsby 1995). One of the most common forms of street art is graffiti, the meaning of which has transformed with time. A contemporary definition of graffiti is "[the] writing or drawings scribbled, scratched, or sprayed illicitly on a wall or other surface in a public place" (OED 2013), and the "illicit" nature of graffiti has generally associated street artists with social deviance and subversion in Western states. ${ }^{10}$ As an unconventional form of public expression, graffiti is viewed as "a form of consciousness challenging conventional processes of legitimization. [...] [However] several street artists / graffitists view the tension as a healthy means of transcendence into conditions where options can be more openly contested" (Rafferty 1991: 77). Subsequently, graffiti and street art are generally associated with rebellious youth and those questioning ownership of expression (Rafferty 1991: 83; Jørgensen 2008). In light of this, street art can provide social scientists with insight into popular grievances and attitudes within varying social, cultural and political circles, particularly in younger generations.

Graffiti and street art can be understood as an important product of a "youth subculture"11 because, as Dick Hebdige argues, it is by making the challenge to the dominant culture visible that youth rebellion and subcultures are most effective: "the challenge to [cultural] hegemony

10 It is important to note that due to its increasing popularity, this form of street art is no longer exclusively synonymous with illegality. Whilst unauthorised graffiti continue to appear in the urban landscapes across the world, commissioned street art has become a means through which graffiti artists and street artists can promote their work and enter into a mainstream art culture.

11 Within sociological research, the term "subculture" has been critiqued for various reasons, including its overtly Marxist reading of youth cultures and an emphasis on class being a primary example. Despite various challenges, it continues to be used in the social sciences. For the sake of my argument I use the term "subculture" in its broadest sense to refer to those actions that are part of the process of young people identifying with, and challenging the dominant culture of their society (Cohen 1972). Whilst arguably a reductionist term used to describe a range of practices, when used in accordance with Cohen's definition, it is useful and most applicable to the situation of the younger generation in Timor-Leste. For an overview of the main schools of thought on youth culture, see Feixas and Nofre (2012: 1-16). For some criticisms of the Birmingham Centre for Contemporary Cultural Studies (CCCS), the term 'subculture' and the existing theories of subcultures, see Bennett (1999: 599-617): Clarke (1974: 428-441); and Debies-Carl (2013: 110-133). 
which subcultures represent is not issued directly by them. Rather it is expressed obliquely, in style [...] at the profoundly superficial level of appearances: that is at the level of signs" (1979:17. Emphasis my own). These visual signs are symbolic representations of the identities and ideas of the young generation that seeks to challenge the Gramscian cultural hegemony or dominant culture in a society (Clarke et al. 1976: 39-42). However, it is often the case that youth subcultures do not solely seek to overcome and radically change the dominant culture. Indeed, there is a tension at the heart of youth subcultures that stems from their inextricable roots in their "parent" culture; as Phil Cohen asserts, youth subcultures are "a compromise solution between two contradictory needs: the need to create and express autonomy and difference from parents, and by extension, their culture; and the need to maintain the [...] parental identifications" $1972: 26$. Emphasis my own). To an extent, the collective identity of a younger generation is constructed round its parental roots and there is a continual conflict between the identification with, and contestation of, the dominant culture.

As visible representations of subculture, street art and graffiti are intrinsically connected to identity construction as "graffiti gives youth the power of self-identity" (Giller 1997). In order to categorise the graffiti in Timor-Leste that gives young artists this power, it is worth outlining the definitions of various forms of street art. Aesthetically, the street art that can be seen on the walls of Dili is reminiscent of murals in terms of the scale and skill involved, while the materials used and unofficial nature of much of the art would suggest that it falls under the general category of graffiti. Within a political context, murals have been defined as "a painting or other work of art executed directly on a wall" (OED 2013) and have predominantly been image-focused since their origins in Mexico in the 1920s, with text included as a secondary component (Anreus et. al 2012). Due to the fact that they are often commissioned, murals typically do not have the negative connotations of criminality that are often attributed to graffiti. ${ }^{12}$ Nonetheless, at its inception the purpose of muralism was similar to the subversive motivations behind graffiti and the incentive to paint murals was to "use [...] visual aesthetics to construct that space of open, public debate between the state and the heterogeneous citizens" (Greeley in Anreus et al. 2012: 3).

In the twenty-first century, murals are still considered to provide a visual narrative of a society and, further, are crucial to fostering a sense of community (Sieber, Cordeiro and Ferro 2012). Bill Rolston affirms the representative and productive function of murals within a collective:

[they are] an integral part of the everyday political scene [...] Sometimes the murals merely reflect the fears and hopes of the community, at others they actually help reproduce the political climate, whether progressive or reactionary. They are not just a backdrop to politics, but a dynamic part of the political process (2003: 14).

In this way, street art and murals are seen as an essential part of the politics of a society, especially one undergoing much transition such as Timor-Leste. However, the nature of the street art in Dili diverges from murals in that they often give primary focus to text, suggesting that they are more comparable with graffiti in which "letters are primary; characters (images, pictures, portraits) are secondary. Graffiti is visual slang” (Jenkins 1995: 34). Moreover, since the 2006 government-sponsored project, much East Timorese street art is unofficial and is not

12 It should be noted that murals in Northern Ireland have not always been viewed in the positive light that now exists. Though murals provide tourism in Northern Ireland with a popular attraction, throughout the Troubles, they were viewed - and are still viewed by some - as hostile images of sectarianism and intimidating markers of territory. For example, see Lisle (2006); and Jarman (1998). 
commissioned. As a form of graffiti, the examples used in this article could therefore be categorised as "pieces" (a "piece" is short for a masterpiece), which are the largest works that combine text and image in large spaces (Giller 1997). This definition is not conclusive but could provide a starting point for a more in-depth analysis of street art in Timor-Leste.

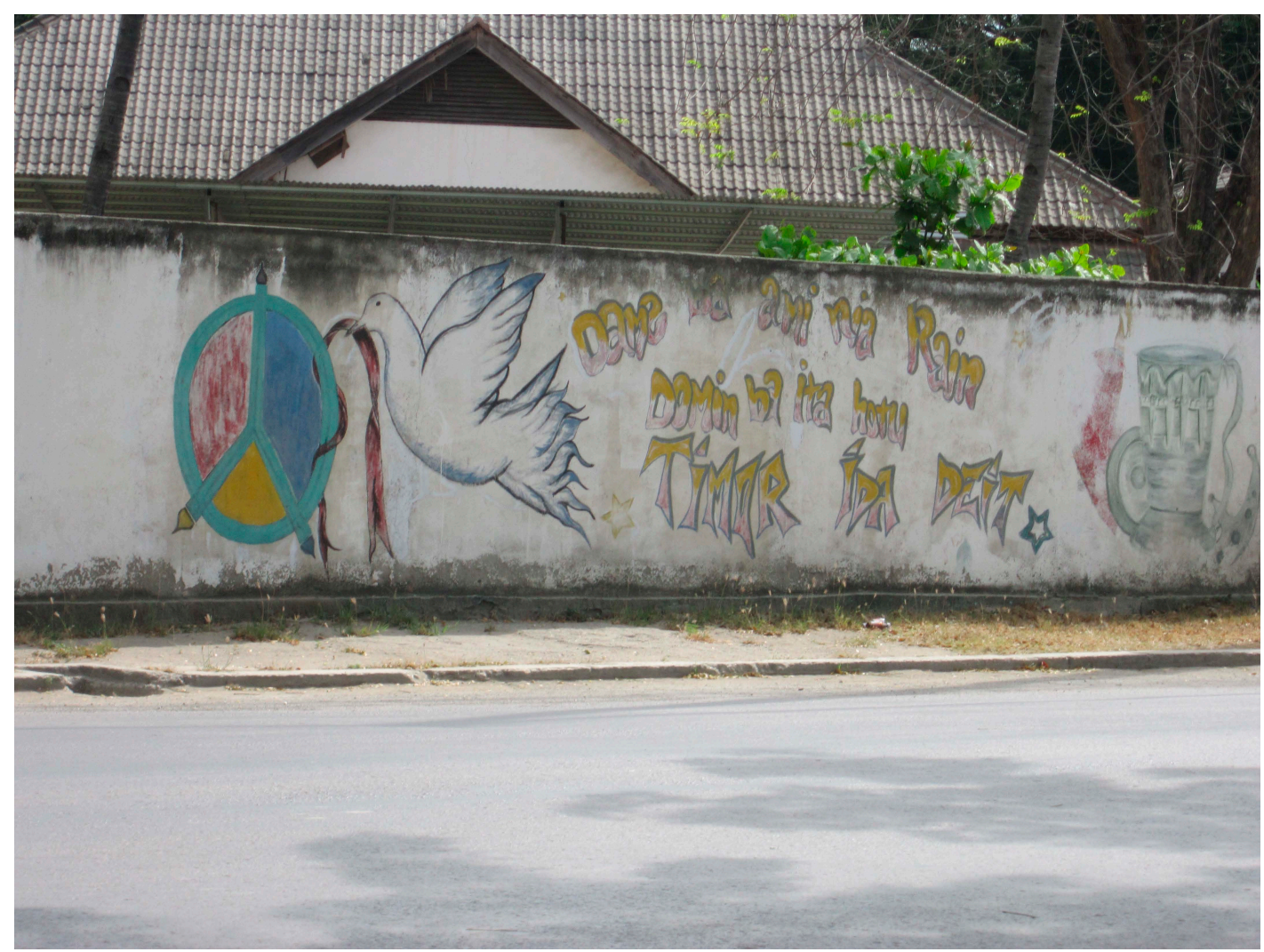

Fig. 1 An example of faded street art in Dili. Photograph taken by the author (June 2012).

Yet it is problematic to define the street art in Timor-Leste simply as graffiti, which is largely understood in many Western states as unauthorised and associated with criminality. Anne Menis asserts this perspective that graffiti are "any writing or drawing, which may be written, sprayed, painted, drawn or etched in or on any publicly accessible surface [...] for which no official provision is made, which are largely unwanted" (2002: 44. Emphasis my own). The majority of street art in Timor-Leste cannot be resolutely described as unwanted due to the simple fact that it is rarely removed from the public spaces where it is found and does not have these negative connotations. The widely recognised importance of street art was recognised and used in 2006 when the East Timorese government commissioned a street art project in Dili to communicate a message of peace and stability to the public at a time of significant political turbulence, caused by a division between East Timorese from the East of the half-island (Lorosa'e) and from the West (Loromonu). ${ }^{13}$ The belief that street art is an effective and popular medium of communication, evidenced by official government endorsement, suggests that the opposition to street art found in some states does not exist in Timor-Leste in the same way. Thus, while most other examples of street art (those which were not part of the 2006 commissioned project) are unofficial, the fact that they are not removed would indicate that they are not necessarily "unwanted." In some instances they stay unchanged on the walls for so long that the

13 For an overview of the 2006 political crisis in Timor-Leste, see Scambary (2009: 265-288). 
colours fade (Fig. 1) and, moreover, some street art that has faded with time is even refreshed and repainted (Fig. 2).

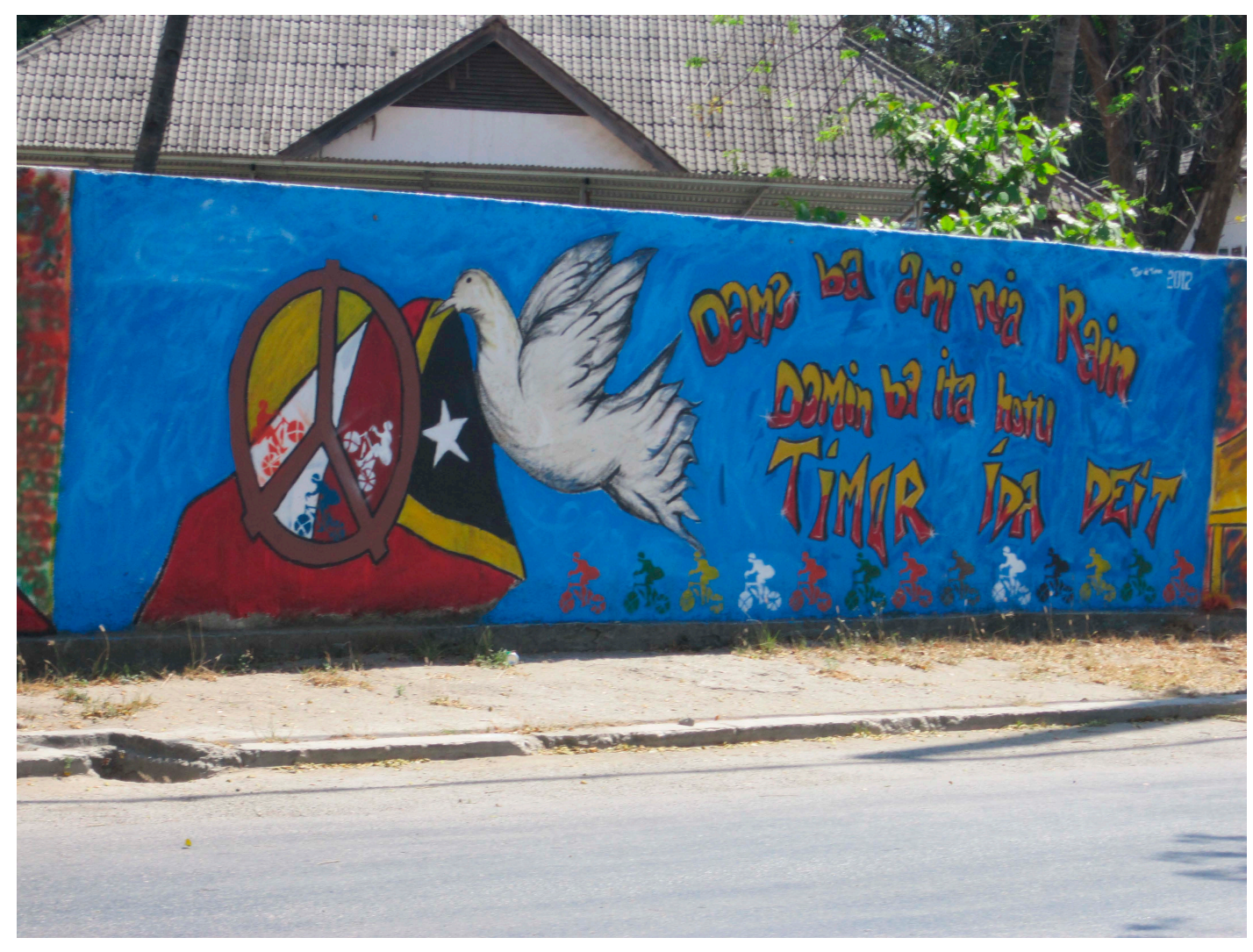

Fig. 2 The same example of street art as in Fig 1, but repainted. Reads "Dame ba ami nia rain, Domin ba ita hotu, Timor ida deit [peace to our land, love to us all, only one Timor]". Photograph taken by the author (Dili, August 2012).

In sum, East Timorese street art could largely be defined as unofficial but appreciated "pieces," as they are left untouched on the walls and tend to focus more heavily on text rather than image. The primacy given to text in these examples facilitates the emission of a direct and explicit message, providing the artists with a public platform for expressing their views and grievances. Crucially, the focus on text highlights the language choices executed in street art and enables an analysis of the cultural and national identification of the street artists with, or in contrast to, the official parent culture of the state.

\section{On the outside looking in: the Geração Foun and the nation-state}

Many members of the younger generation in Timor-Leste have a great incentive to publicly express and identify themselves in the post-independence years, in light of the fact that generational differences have led to their isolation and under-representation in politics. Due to the successive foreign occupations by Portugal and Indonesia, the legacies of two divergent cultural heritages exist in the post-independence state, which are central to the collective identification of the respective generations. The decision to adopt Portuguese as a national language and construct an East Timorese national identity with Lusophone roots has elevated the status 
of the "Generation of " 75, ,"14 and meant that those born and educated under the Indonesian occupation have found difficulties in fully identifying with their fellow East Timorese. ${ }^{15}$ Critically, contemporary statistical evidence indicates that the younger generations (the Geração Foun and the "independence generation") constitute more than 60 per cent of the population (UNDP 2011: 23). The younger generations in Timor-Leste thus make up a notable majority, rendering the issue of their representation and the privileging of the Generation of '75 a pressing issue in national politics.

Upon gaining independence in 2002, the unity that was fostered under the resistance movement needed to be institutionalised in the new nation-state to prevent and overcome potential emerging divisions. Angie Bexley affirms that "the situation of independence has triggered a relentless search for the 'pure'Timorese identity" and the process of national identity construction focused on the recent struggle for independence as the foundation of "true" East Timorese-ness (2007: 86). The history of Timor-Leste has been articulated through an occupier-occupied paradigm, with the concept of the struggle (funu) at the heart of national historical narratives and identity construction. In addition, the brutality that was endured by the East Timorese people under Indonesia brought about a sense of solidarity and unity through suffering (terus). ${ }^{16}$ Consequently, these elements are "essential in the public performance of identity in order to gain legitimacy as national subjects in independent Timor-Leste" (Bexley 2007: 73). Within this paradigm, members of the Generation of "75 who lived through the occupation are regarded as those who suffered and contributed most towards the liberation struggle. This is despite the fact that numerous youth and student resistance organizations existed under the Indonesian occupation. For those young East Timorese that participated in the resistance movement, the absolute precedence given to the Falintil (Forças Armadas para a Liberação Nacional do Timor Leste) and the political leadership of the liberation movement has overshadowed a significant number of youth resistance organizations, such as RENETIL (Resistência Nacional dos Estudantes de Timor-Leste), OPJLATIL (Organizasaun Popular da Joventude Louriku Assuain de Timor Leste) and the LEP (Liga dos Estudantes Patriotas). ${ }^{17}$ With their participation in the liberation struggle largely overlooked, Jill Jolliffe describes the Geração Foun as "Timor's best and brightest - who feel they have been denied a chance to participate in the society for which they sacrificed all". ${ }^{18}$ The younger generation are seen as unable to claim the same level of legitimacy as the older generation and as a result, they have become what Matthew Arnold terms "a generation detached from the solidarity experiences of Timor-Leste's resistance era" and overlooked in the process of nation-building that is largely founded on the struggle for independence (Arnold 2009: 380); a reality which is in stark contrast to the pursuit of an inclusive collective identity and national unity.

14 The "Generation of " 75 " refers to members of the older generation as they formed the national leadership during the brief period of independence in 1975 (International Crisis Group 2011: 18).

15 The privileging one cultural-linguistic heritage over another did not, however, signal a complete negation of the older generation's criticisms of colonialism. The national identity was to be constructed round the history of resistance, but the older generation "continued to value Portuguese language and culture as longstanding and wellintegrated elements of East Timor's national culture” (Hull 2000).

16 There is a popular perception that those who stayed in Timor-Leste and suffered under the Indonesian occupation are the "true" East Timorese and more legitimate members of the national community. See Traube (2007: 9-25).

17 For a comprehensive list of the youth resistance organizations see Fox and Babo Soares (2000: 63).

18 2011, The Monthly: http://www.themonthly.com.au/issue/2011/march/1301812693/jill-jolliffe/postcolonialblues 
In addition, the identification of the Geração Foun with Indonesian culture and language places in doubt the legitimacy of their claims as "true" East Timorese in the eyes of the older generation and official state narratives (Bexley 2011). By culturally identifying with the most recent foreign occupier, the younger generation's claims to legitimate nationhood are seemingly undermined in light of the occupier-occupied narratives. The affiliation is viewed so antagonistically that members of the older generation have referred to them as the Generasi Supermi (the Supermi generation), which has several negative connotations (Bexley 2011). Supermi instant noodles are an import from Indonesia and the reference to young people in this respect associates them with softness (like the noodles), an "instant" attitude towards life that opposes traditional values and a lack of experience and leadership qualities (Bexley 2011). The derogatory label and implications are combined with the cultural and linguistic ties of the younger generation to Indonesia, resulting in a stark cultural alienation from the rest of East Timorese society that is recognised as legitimate subjects of the nation.

Within this context, street art has become an accessible means of expressing views and asserting identity for the Dili artists as members of the Geração Foun. It enables them to communicate with - and challenge - the Generation of "75 and the apparent exclusivity of the nation-building project. MacDonald argues that "graffiti's rewards are manifold, but there is a thread connecting them. Put together, they articulate a process of change and development, transition and progression" (2001: 228). The change, transition and progression that street art aims to achieve are also the aspirations of the Dili artists in relation to their socio-political situation. As one artist states, contestation is a primary function of graffiti:

Because often, the artist paints about politics because there's a small problem with the nation. Often it's like the government doesn't do something well, or make the people happy, so the artist tries to paint something to 'provoke,' $[\ldots]$ so that they see and learn (personal interview, Dili 24/0/2012). ${ }^{19}$

Not only do the young graffiti artists demonstrate an attempt to relate to the older generation through street art but they seek to challenge the apparent problems of their society, which include the institutionalised perceptions of 'true' East Timorese-ness, based on a Lusophone heritage. These "contradictory needs" of the youth subculture (Cohen 1972: 26) are exemplified in the language choices made in street art because one of the divisive elements of the institutionalised cultural heritage that has thus far estranged these artists, as members of the Geração Foun, is exogenous language use.

\section{Atu koalia Tetun, Bahasa ka Portugues? language Choices of the Geração Foun}

Any nation-building project involves the selection of (an) official language(s) as language is a key marker of national identity and an integral part of nation-state politics (Grin and Kymlicka 2003: 11; Borgerhoff 2006: 111-118). In 2002, the then President Xanana Gusmão delivered his independence speech in four languages, which gives some insight into the complexity of the East Timorese case. ${ }^{20}$ Official language policy continues to be a contentious issue

19 "Tamba dalan barak hanesan artista nia pinta kona ba politik tamba hanesan iha problema ituan ho nasaun. Dalan barak, hanesan governu la dun halo boat nebee, halo ema kontenti, entau artista koko atu pinta boat nebee mak, hanesan 'provoke,' ... atu sira haree no aprende." Translated from a transcript in Tetun, translation my own.

20 An exact number of indigenous languages and their classifications is yet to be established, but estimates suggest that there are around twenty (see Hajek 2002: 182-202). 
and the specific situation of the younger generation is symptomatic of the lack of consensus on which languages can be spoken by 'true' East Timorese citizens. Since self-determination, the national political leadership has continually been comprised of members of the Generation of '75, allowing for their cultural-linguistic heritage to be reflected in official state narratives and policy. The fact that the Portuguese language has been enshrined as an official language within the 'sacralised' Constitution of the state, alongside Tetun, exemplifies the privileged status of the older generation and consequently, the distancing of the Geração Foun (Leach 2003: 138-140). Ego Lemos has articulated this sense of estrangement as follows:

Most of generation foun are still unhappy about the way they've been treated. Firstly, concerning opportunities, I think they've been left out - nobody thought about what they could contribute after independence. Secondly, it's about language, it is still a big barrier [...] we had no chance to learn like those who lived abroad [...].The government decided on Portuguese as an official language but the new generation didn't speak it [...] The leaders decided it without considering every aspect of this generation (cited in Jolliffe 2011. Emphasis my own).

Indeed, the percentage of East Timorese that are fully competent in the Portuguese language is relatively low - some 36 per cent (Taylor-Leech 2009: 15) - which suggests that only a minority of the population are able to access this source of cultural power and identity.

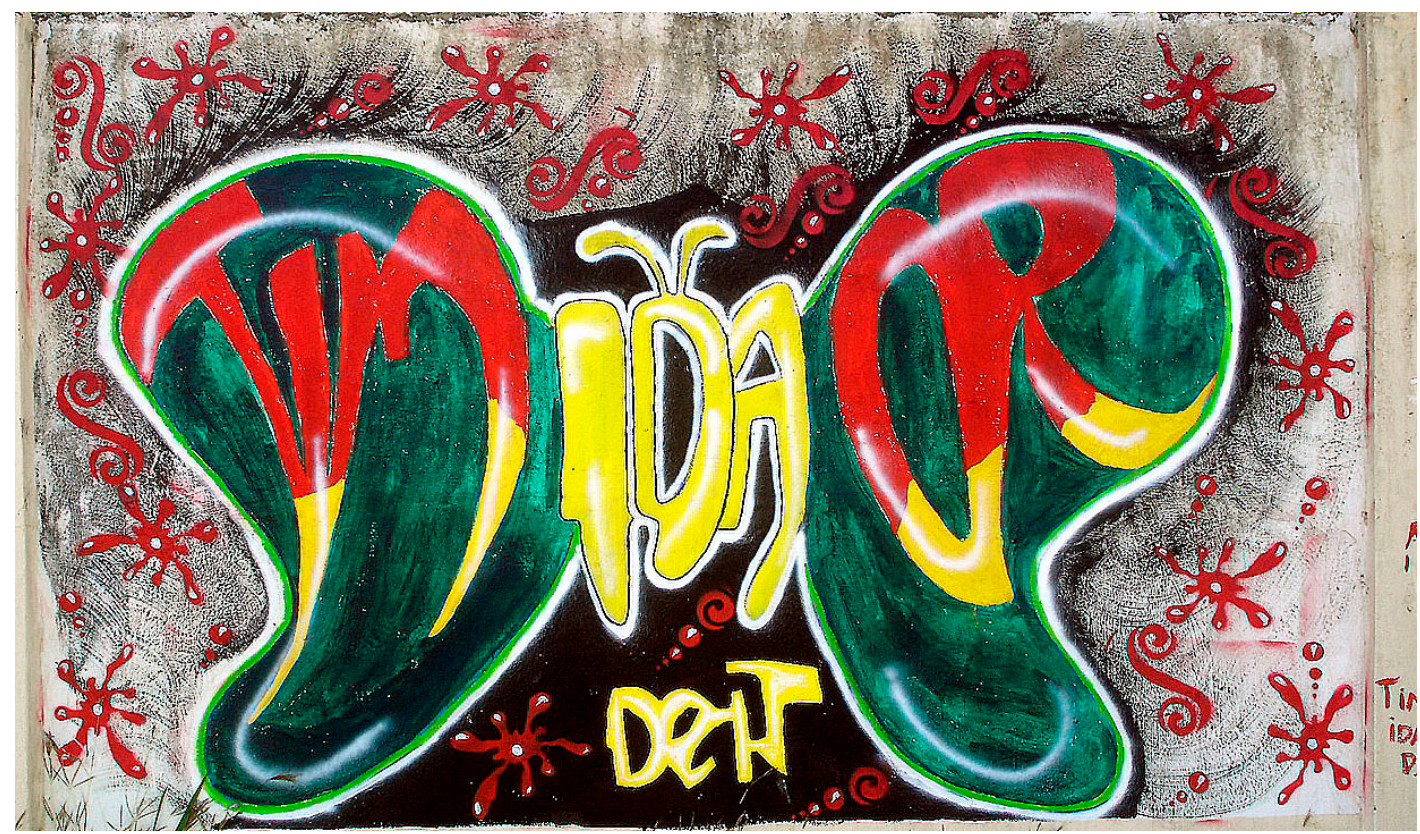

Fig. 3 “Timor ida deit”(“only one Timor”). Image by artists from the Centro Arte Moris (Dili, 2006).

In Timor-Leste, language use is directly influenced by the educational and cultural background of the respective periods of occupation. In terms of exogenous language use, it is estimated that 90 per cent of East Timorese under the age of 35 speak Bahasa Indonesia (Leach 2003: 140), despite state policy endorsing Portuguese language classes in primary and secondary education and no official education in Bahasa. ${ }^{21}$ Capabilities in Bahasa come second only to those in Tetun; Michael Leach's research has highlighted that 91.5 per cent of young East

21 It is noteworthy that the policy of Portuguese as the language of education in primary and secondary education has proven so problematic that it is currently under revision. Portuguese was chosen as the language of delivery in the classroom because Tetun was considered too "rudimentary." However, low literacy levels continue to present a real problem and as such, language in education must be reconsidered. See Du (2013). 
Timorese self-identify as fluent in the lingua franca. Within the same study, only 2.5 per cent self-identified as fluent Portuguese speakers (2003: 144). ${ }^{22}$ In light of these statistics, one might anticipate that the primary languages to appear in street art would be Tetun and Bahasa, with minimal or no use of Portuguese in graffiti. However, the tension between the desire of the Dili artists to simultaneously challenge and to identify with the dominant culture in Timor-Leste has produced street art that exposes deliberate language choices that include Portuguese.

The following case studies are pieces from Dili that feature Tetun and Portuguese, as well as a combination of the two in what Obeng terms "codemixing" and "codeswitching," or "the graffiti discourse [in which] participants switch from one language to another within the same sentence" (2000: 360-361). While my examples are taken from the capital, the artists with whom I spoke stated that they also produce similar art in other towns and districts (personal interview, Dili 25/07/2012). The decision made by the young street artists in their work to incorporate Portuguese indicates an awareness of the official sources of cultural power and identity. The use of Tetun as a universally understood language is employed for its efficacy and as a means of contesting the dominant Lusphone culture of East Timorese society. In this way, the street artists are able to use this form of graffiti to directly express and contest their alienation from the nation-building project thus far.

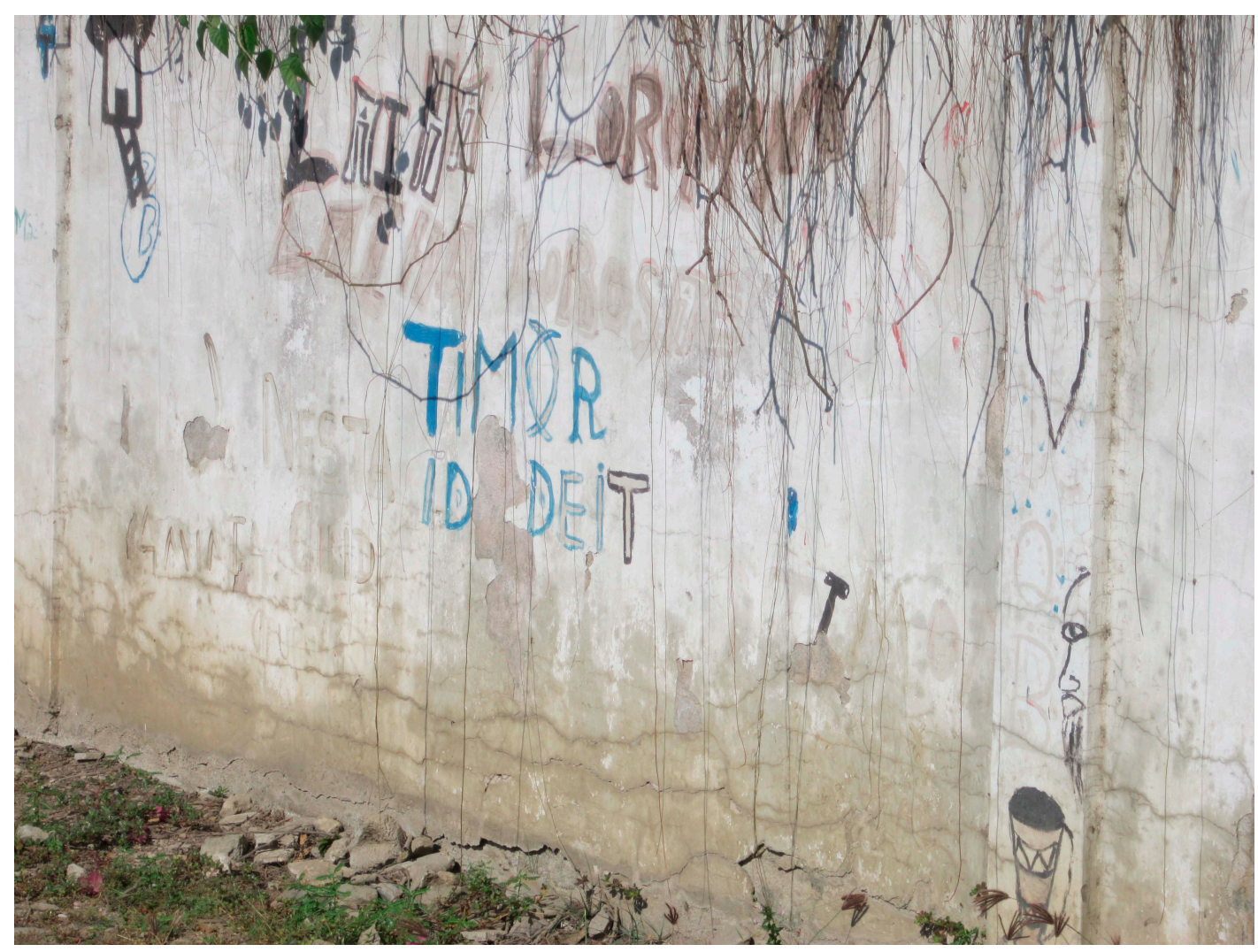

Fig. 4 “Timor ida deit”, artist unknown. Photograph by the author (Dili, July 2012).

22 Leach's study explores the use and proficiency of Tetun-Dili specifically as an official state language. 


\section{Paz / Dame: Messages of Peace and Unity in Street Art}

The future of Timor-Leste is the focus of much street art and messages of peace, unity and stability dominate the pieces on the walls across Dili. It could be argued that the incorporation of these themes in street art began with the 2006 crisis which prompted the project of street art, commissioned by the East Timorese government. In the midst of political turbulence and civil disorder, the project was intended to provide an alternative medium of communication to engage those involved in the violence. José Ramos-Horta stated that the objective was "to produce a graffiti campaign promoting peace, unity, mutual tolerance and friendship" (cited in Parkinson 2010: 4-5). ${ }^{23}$ By commissioning a project to promote these ideals, it might be argued that it was the government - formed by members of the older generation - that instigated the recurrent themes of peace, stability and unity in street art and, therefore, the use of such rhetoric in graffiti was simply a re-presentation of the dominant government discourse at the time. Yet, since the end of the project similar themes and messages have continued to appear in unofficial, uncommissioned street art, suggesting a continued desire from the artists to advocate peace, stability and national unity years after the 2006 crisis was resolved. In this way, these members of the Geração Foun can be seen to identify with the parent culture through adopting its discourse and sharing its hopes for the future of the state. However, the tension between identification with and a critique of the dominant parent culture is also evident in the emphasis given to certain aspects of this vision. By analysing the language choices made to convey the message of the street artists, we can reveal this tension more clearly.

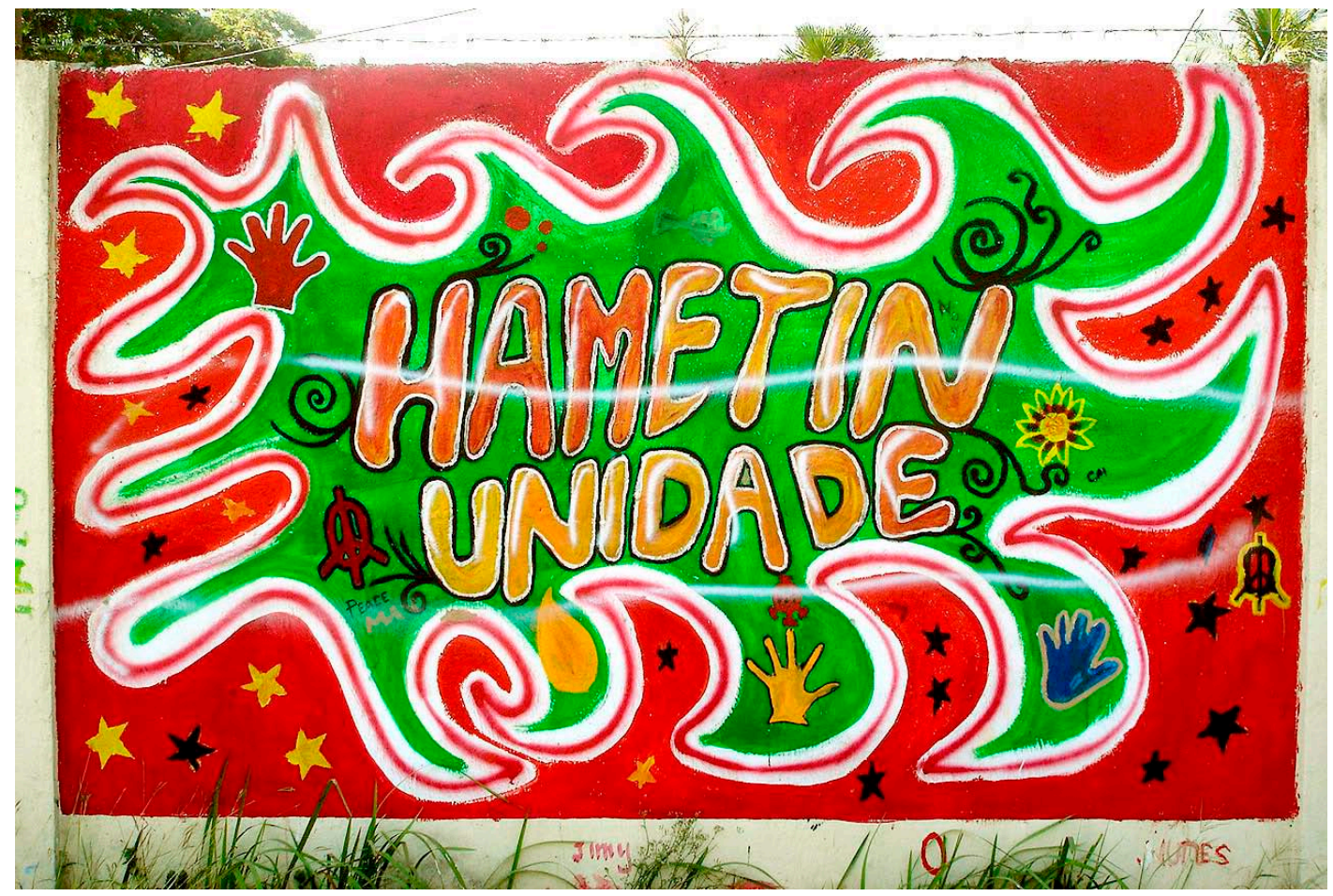

Fig. 5 “Hametin unidade”(“strengthen unity”). Image by artists from Centro Arte Moris (Dili, 2006).

23 José Ramos-Horta temporarily held the office of prime minister of Timor-Leste at the height of the 2006 crisis, following the resignation of Mari Alkatiri from the premiership. 


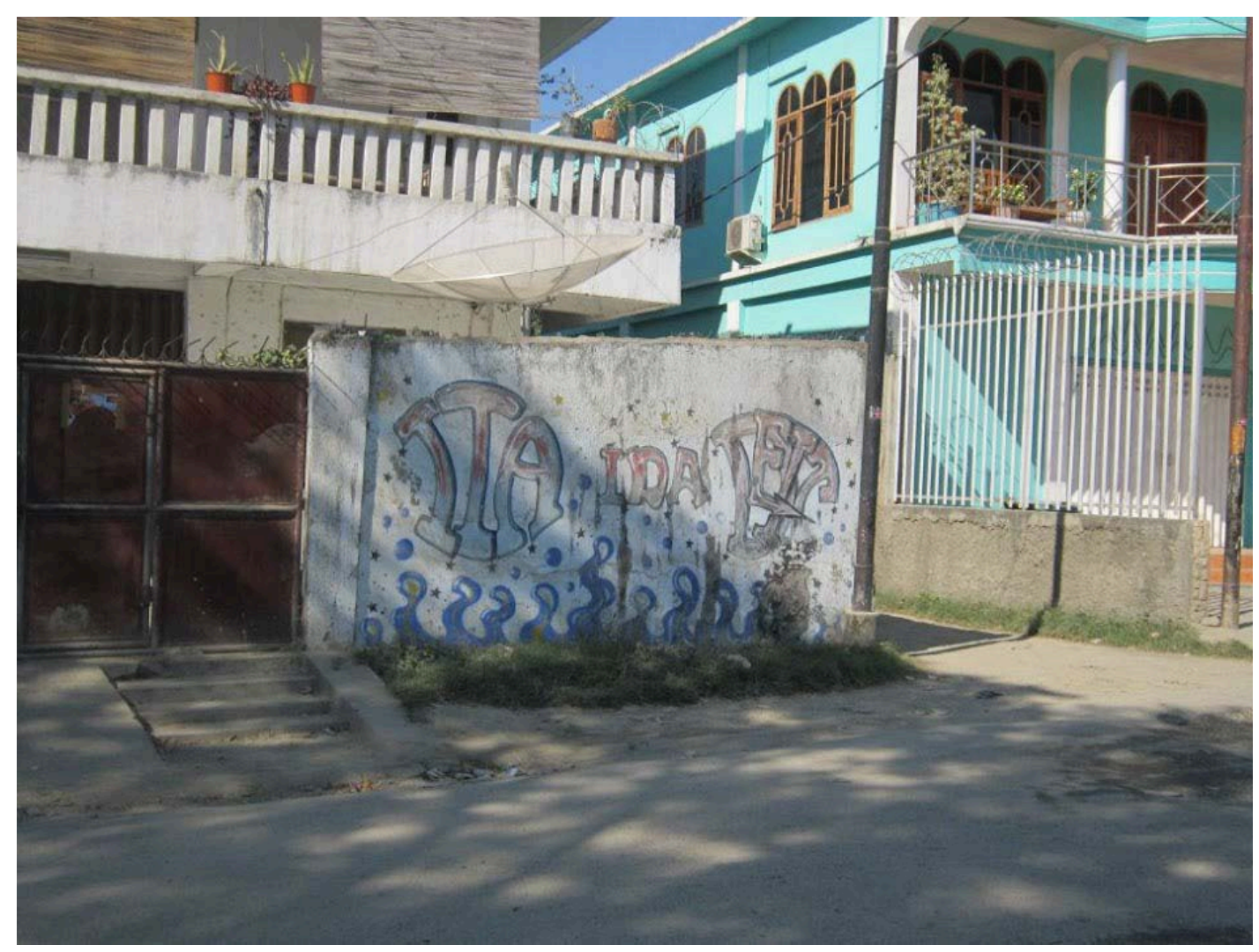

Fig. 6 "Ita ida deit” (“we are only one”). Photograph taken by author (Dili, July 2012).

Pieces of street art facilitate an explicit dissemination of messages and discourses as a result of the technique's focus on text. References to unity and solidarity in graffiti, such as "Timor ida deit" ("only one Timor," Figs. 3 and 4), "Hametin unidade" ("strengthen unity," Fig. 5) and "Ita ida deit" ("we are only one," Fig. 6), are significant and visible markers of the young generation's desire for national unity. ${ }^{24}$ The initial calls for national unity through street art were instigated during the 2006 crisis. While the messages of unity at this time emerged within the specific political context of the East-West divide, the continuation of this theme in street art since then suggests the importance of national unity for the artists in their political viewpoint. Indeed, the theme of national unity has been repeatedly painted on the walls long after the 2006 crisis was resolved, indicating that any social division would be viewed as a challenge to be overcome for the national community - including the generation gap. In light of this, it could be asserted that the marginalisation of the younger generation is implicitly referenced by the clear calls for an inclusive nation, free from exclusivity and the isolation of any of its members. Presented in a positive way, a criticism is made of the Generation of '75 and the way in which the nation-building project has been carried out to date. The theme of national unity in street art in particular indicates a furthering of the idea that the younger generation should be included in the national community as accepted legitimate members.

In these examples, the importance of unity for the young artists is further underlined by the strategic language choices made in the graffiti: the use of Tetun makes the message accessible to both the older and younger generations and could itself be seen as a unifying force. While Tetun is not as yet fully standardised, it is an official state language and is the most

24 The images from 2006, as specified, were kindly shared with me by the artists at Centro Arte Moris (Dili) from their archives. 
widely used language common to both generational groups. ${ }^{25}$ The way in which these phrases are constructed in Tetun emphasises the message of unification and inclusion in a collective. In these pieces, the language used by the graffiti artists invokes a sense of togetherness through the use of a collective 'we' - ita - in creating the idea of a unified East Timorese community, as opposed to the more exclusive $a m i{ }^{26}$ Obeng highlights that this is a graffiti technique used throughout the world: "graffitists [...] use inclusive and exclusive pronouns - we, us, our, they, them, and their - [...] to show closeness or co-membership" (2000: 342). This inclusive Tetun terminology is arguably chosen to illustrate these members of the Geração Foun's desire for membership in the collective from which they have been ostracised, as well as the unity that is integral to their vision for the future of the national community.

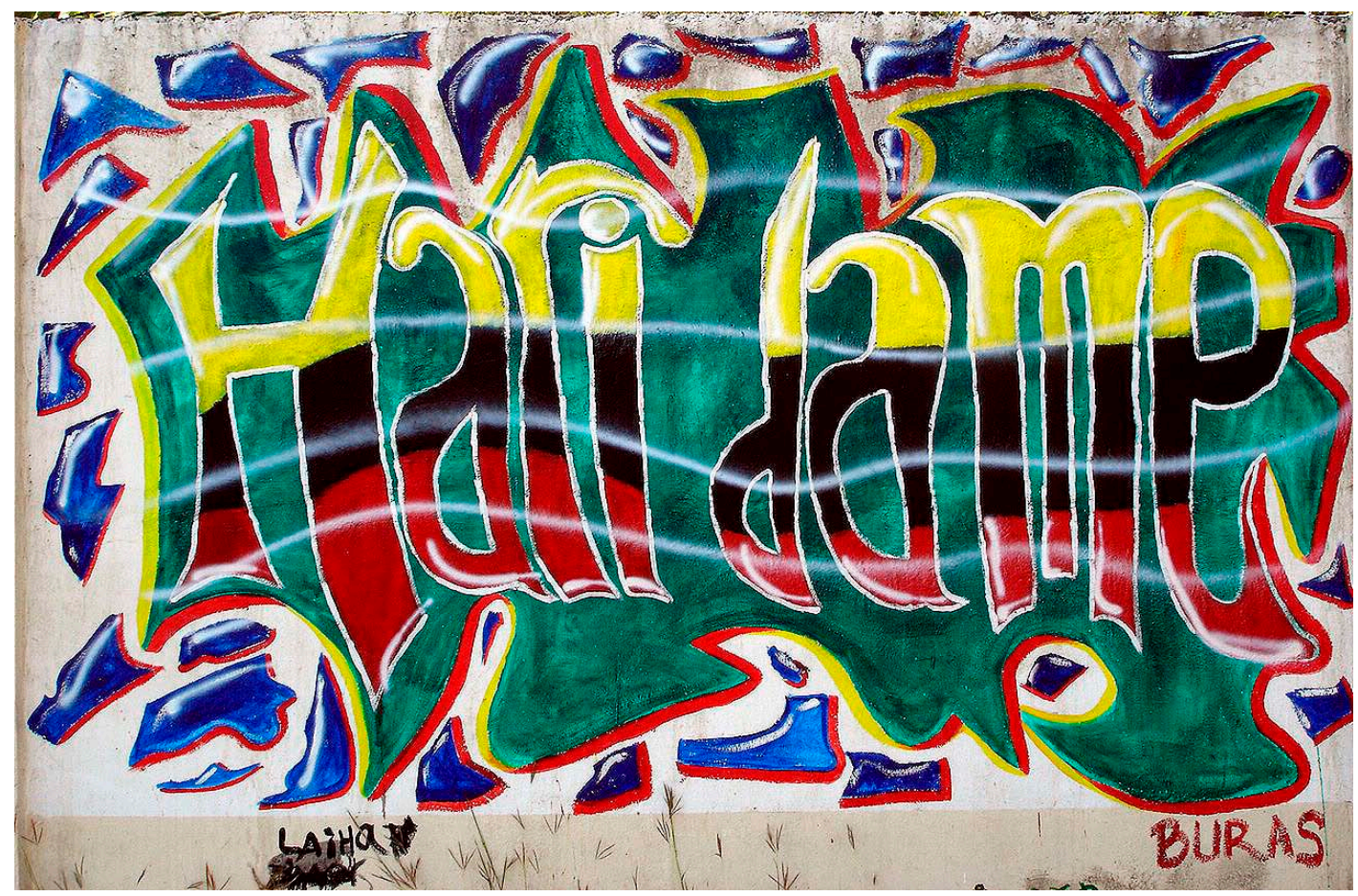

Fig. 7 "Hari dame" ("build peace"). Image by artists from Centro Arte Moris (Dili, 2006).

The following examples are also linguistically constructed to project a positive vision for the future: stating "Hari dame" ("build peace," Fig. 7) and "Haburas pas no domin" (literally, "make thrive peace and love," Fig. 8), they outline direct instructions in Tetun. The prefix " $b a-$ " is a contraction of the verb "balo" which translates into English as "to make" (Thomaz 1981: 59); attaching " $h a-$ " to a verb therefore signifies an incentive for the action or verb to take place. A combination of a causative verb " $b a^{-}$" and the terminology of peace and unity thus demonstrates the artists' desire to achieve this positive vision that has not yet been realised in Timor-Leste, led by the older generation. Chris Parkinson attests that "the trends [in street art] are more about hope. There's certainly a conscious movement amongst some of the graffiti

25 The East Timorese government has endorsed the enactment of the 'Standard Orthography of the Tetum Language' to further standardise the language (see Democratic Republic of Timor-Leste Government 2004). While this and other on-going projects continue to work on the Tetun vernacular, the configuration of the language is sufficient for it to be practically used in everyday life (in the media, such as newspapers, television etc). 26 'Ita' is a subject pronoun used by the first person plural, but implies inclusivity. The alternative subject for 'we' in Tetun is 'ami, 'which implies exclusivity and is used when addressing someone from outside of the in-group. See Geoffrey Hull (1999: 6). 
artists in the country today to be painting what they want to see" (Peace of Wall - Street Art from East Timor Blogspot, http://peaceofwall.blogspot.co.uk). By constructing phrases in Tetun - a language common to both generational groups - this positive outlook can be disseminated, received and understood by all members of the national community, including the political élite and the older generation.

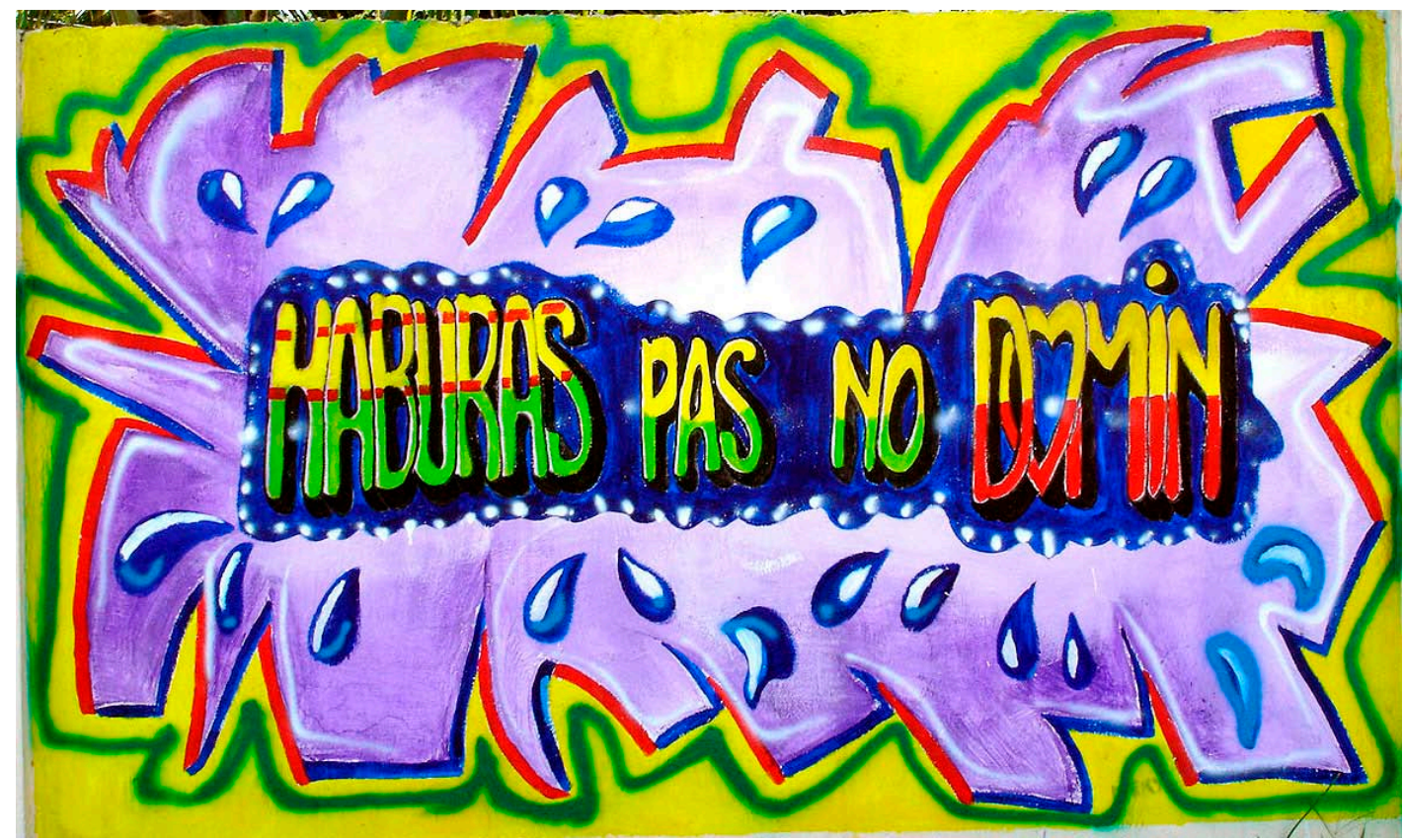

Fig. 8 "Haburas pas no domin" ("make thrive peace and love"). Image by artists from Centro Arte Moris (Dili, 2006).

It is important to note that Portuguese vocabulary has become a strong component of the Tetun language and is seen by some to complement it as a co-official language (Leach 2003: 140). It is perhaps inevitable, therefore, that the relevant Portuguese words would also be incorporated into street art. For example, the words paz, livre, unidade and estabilidade are used alongside their Tetun equivalents in the following case in point (Fig. 9). Speaking about this particular piece, an East Timorese artist outlined the centrality of language in the 2006 project as follows:

This one, we did before, in 2006. Before, back then, there was a big problem between 'East-West.' So we did this one about a new language which is connected to love, to peace, to freedom, to peace. Like the dove flies free. [...] It is connected with politics because at that time there was a big problem (personal interview, Dili $24 / 07 / 2012) .{ }^{27}$

The involvement of the East Timorese government in the 2006 project clearly influenced the content of the art, and an analysis of language choices elucidates the ways in which the younger generation identified with the parent culture, not only though the ideals and messages emitted but also through the preferred exogenous language of the Generation of '75. Despite the fact that this example was painted in the context of the East-West conflict, the concept of national unity continues to be understood to be of vital importance from the perspective of

27 'Ida nee, ami halo uluk iha 2006. Uluk, iha nebaa, iha problema boot entre 'East-West.' Entao, ami halo ida nee kona ba lian foun nebe mak iha nia 'connection' ho domin, ho dame, ho livre nian, ho paz. Hanesan nee manu semo livre ... konekta ho politika tamba tempu iha nebaa iha problema boot." Translated from a transcript in Tetun, translation my own. 
these members of the Geração Foun. As one artist notes,

Paz, dame, domin, unidade, are very important for everyone [...]. Before our people used violence to get the right to independence and now we have peace. Sometimes the situation obligates us to use conflict, but now, not only me but all Timorese people, want peace (personal interview, Dili 28/07/2012). ${ }^{28}$

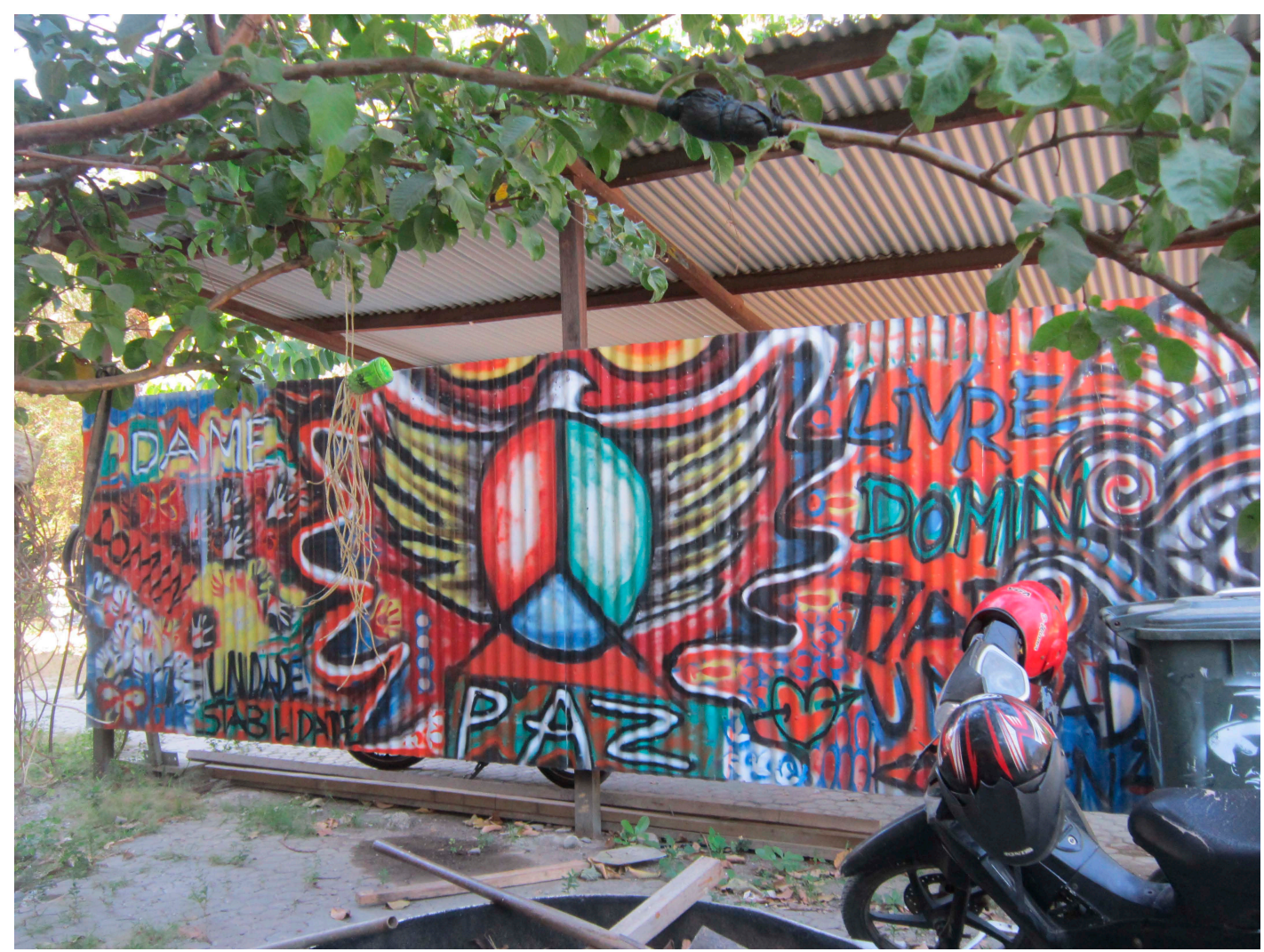

Fig. 9A 'piece' at the Centro Arte Moris using a selection of Portuguese and Tetun words. Photograph taken by the author (Dili, July 2012).

Peace and unity are understood to be inextricably connected and this is reflected in the art that is produced. As a result, it could be concluded that the generation gap, as one of the prevailing social divisions of the post-independence state, is seen by these younger East Timorese as an obstacle to be overcome.

Even though the messages of peace and unity were unquestioned by the street artists, their choice of language in this example (Fig. 9) is worth noting because it is precisely the apparent favour shown to a Portuguese cultural-linguistic heritage by the political elite that has contributed to the alienation of the younger generation, who have a more limited knowledge of the language. As Fernando de Araújo summarises, for the young people who hold no attachment to a Lusophone heritage, the Portuguese language remains foreign:

[the] Portuguese language is the same as Bahasa Indonesia - the colonialist language. If you want to use Portuguese, it's OK, but you cannot say that this is our East Timorese identity. We have our identity. [...] I don't want to use this language that's just spoken by the elite, or by one group. It's a kind of alienation (cited in Leach 2003: 141-142).

28 Interview conducted in English. 
Considering this viewpoint, the young graffiti artists' inclusion of Portuguese vocabulary written alongside their Tetun equivalents could be seen as unusual or superfluous. Indeed, in the event of adopting an exogenous language, Bahasa Indonesia would perhaps be a more likely choice given the educational and linguistic background of many East Timorese young people. An analysis of the visual representation and construction of the pieces, however, is crucial to understanding the motivations behind these language choices.

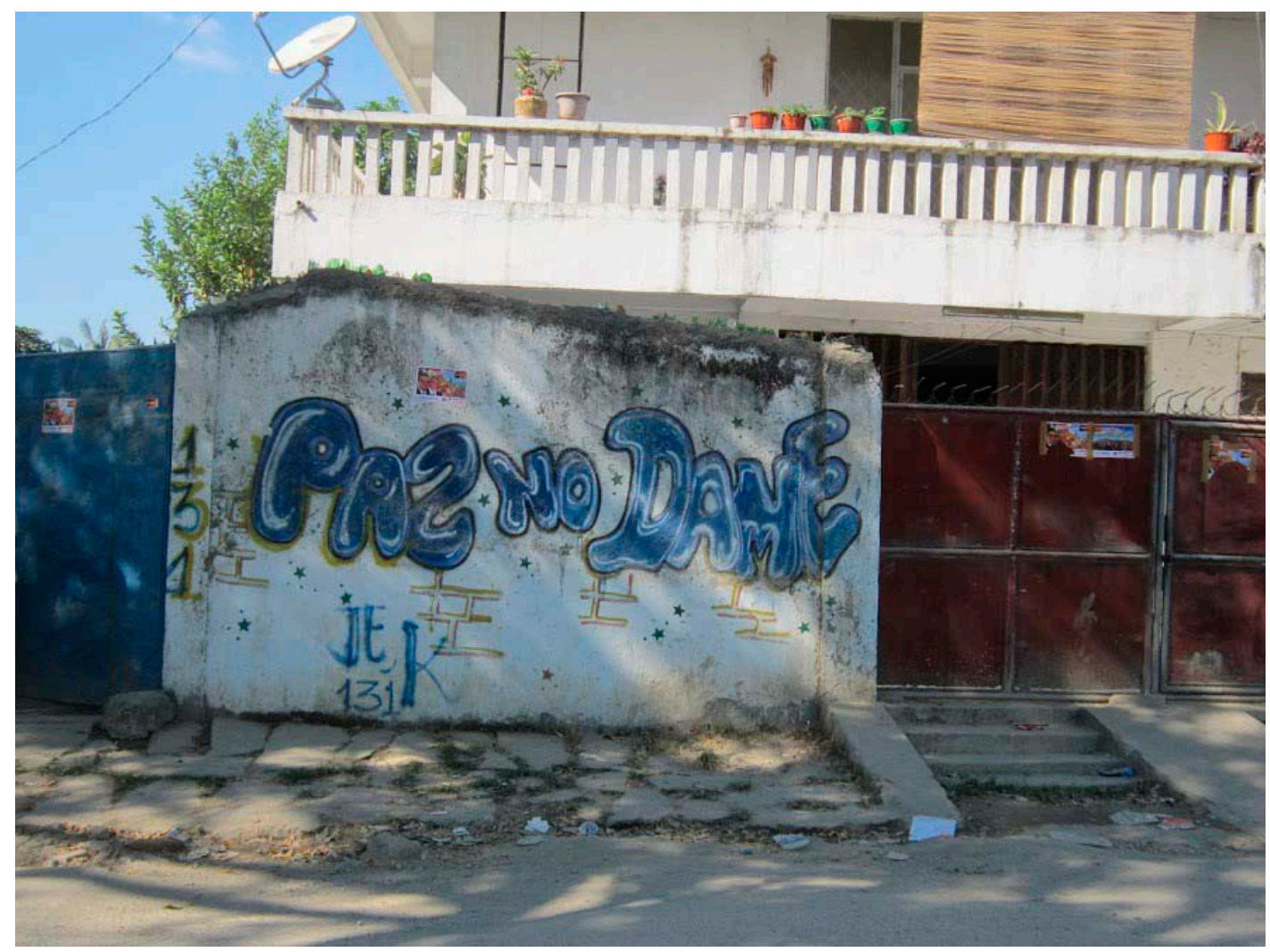

Fig. 10 "Paz no Dame" - the Portuguese and Tetun words for peace. Photograph taken by the author (Dili, July 2012).

The following piece incorporates Portuguese into its message and exemplifies the concept of code-mixing, or using more than one language in a given phrase (Fig. 10). In this example the Portuguese word "paz" is used concomitantly with its corresponding Tetun term, "dame," despite the fact that they hold the same meaning (peace). Speaking about this particular piece, one street artist stated "paz, dame. It's the same' (personal interview, Dili 24/07/2012). It is important to note that "paz no dame," or "halo dame," are terms commonly used to refer to reconciliation ceremonies across Timor-Leste, and are a means of conflict resolution at a local level (for example Simião 2005). ${ }^{29}$ However, during my discussion with the artist, who painted this piece in 2006 with colleagues from the Centro Arte Moris, the cultural reference to the reconciliation ceremony was not indicated; only the words used, their meaning of peace and its relevance to the political situation in Timor-Leste. The fact that the authors of this piece made no reference to the reconciliation ceremonies is noteworthy and in fact expounds the focus that was instead given to the words and language employed.

29 I would like to especially thank Kelly da Silva for bringing this point to my attention. 
In this respect, the presentation of the words and their aesthetic construction can be seen as telling of perceptions of status with regards to the respective cultural-linguistic heritages. Arguably, there are three main reasons for the use of both Portuguese and Tetun in street art in this way. First, a balanced selection of words from the two languages presents an understanding that they have an equal status. Portuguese is not privileged above Tetun and, therefore, the cultural-linguistic heritage of one generation is not given any more authority than the other. If no superiority is attributed to either generation's cultural background, then questions over the legitimacy of the Geração Foun's claims to true East Timorese-ness are perhaps no longer pertinent. Second, the use of both languages can further facilitate a sense of unity through acts of visual communication that symbolically overcome the generation gap. As the young graffiti artists adopt elements of the language that would usually contribute to their cultural alienation, their pieces suggest that dialogue with the older generation is possible. Third, the appropriation of Portuguese vocabulary by the younger generation could be seen as an attempt to legitimise their visions for the future of Timor-Leste. Adhering to the institutionalised understanding of true East Timorese-ness that incorporates a Lusophone heritage, the artists use Portuguese to access the symbolic sources of cultural identity in the post-independence state. By adopting the exogenous language associated with validity, the message of these members of the younger generation is arguably legitimated in the eyes of the Generation of '75. The graffiti artists adapt to official notions of legitimacy and, consequently, their message is presented as one that is credible and worthy of consideration.

\section{Subversive Street Art: a Critique of the Generation of '75}

While an attempt to overcome the generational divide has been demonstrated in the graffiti advocating peace and unity, East Timorese street art can equally provide a critique of the Generation of "75. The predominance of the Lusophone cultural heritage and the emphasis placed on the recent past of Timor-Leste - characterised by the resistance to Indonesia - are implicitly presented as counter-productive to a nation-building project in the present. Indeed, the centrality of the struggle for independence (funu) to national identity construction arguably stands in contrast to the dominant discourse of peace and stability that has emerged since 2002 . By focusing instead on the future of Timor-Leste, the young artists present their position in a way that implies that they are the true advocates of peace who are genuinely concerned with this aspect of the nation-building project. The following graffiti, reading "Timor nia kultura laos funu maibe dame" ("Timorese culture is not war but peace," Fig. 11), exemplifies the distinction made by the artists that projects a positive outlook for the future.

The language choice in this example is particularly telling of a political viewpoint and an implicit critique of the older generation. This is typical of the subversive function of graffiti: "[the] languages have not been chosen at random, but have been chosen because of the stereotypical values more or less ascribed to them, as well as the connotations carried by the individual words" (Jørgensen 2008: 247). In creating this piece, the street artists revert back to Tetun and do not incorporate any Portuguese vocabulary into the graffiti. There are several potential reasons for this language choice. First, the Tetun word "funu" has been central to national narratives and identity construction; the connotations of this word are inescapably linked to official notions of "true" East Timorese-ness, underlining the critique of institutionalised identity narratives. Second, Tetun is employed as a universally-understood language to ensure direct and 
effective communication to all East Timorese, across the generation gap. Third, the decision to not use Portuguese in this example distances the Geração Foun from the Lusophone heritage of the older generation. The Generation of ' 75 is seen to have participated more directly in the struggle for independence and its members therefore revere it as a core tenet of an East Timorese national identity. In order to demonstrate the artists' position of opposing conflict and as the advocates of peace and stability in the nation-state, the older generation's preoccupation with the struggle is challenged. The critique of the parent culture infers that the focus on the violent struggle for independence is too overbearing in the post-independence state, where the primary concern should be peace-building.

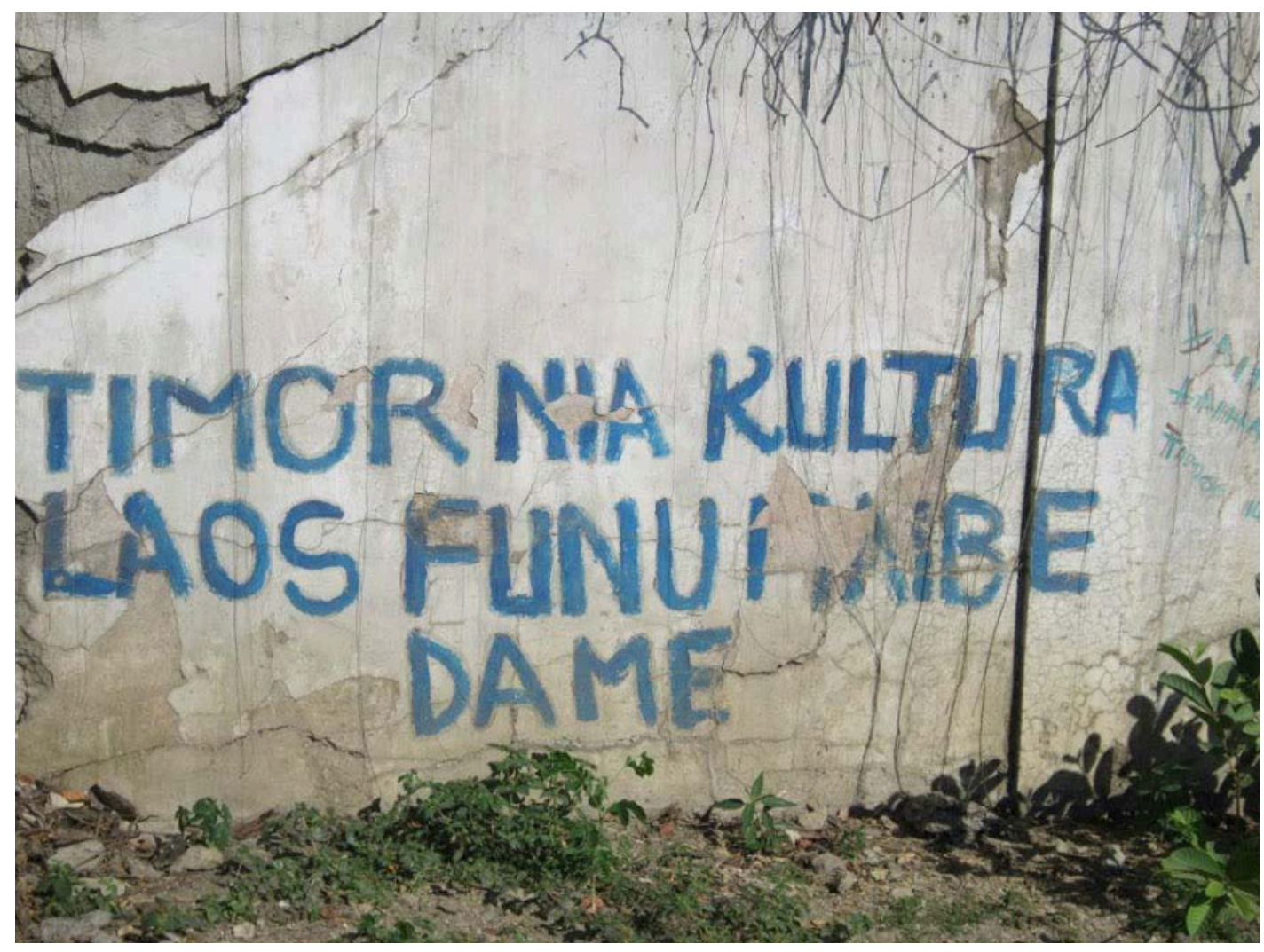

Fig. 11 "Timor nia kultura laos funu maibe dame" ("Timorese culture is not war but peace"). Photograph taken by the author (Dili, July 2012).

This criticism of the Generation of ' 75 perhaps stems from an apparent contradiction in the dominant discourse of the political elite. While peace and unity have been promoted frequently and fervently in state narratives since 2002, a focus on the violent struggle for independence is one of the central points of national identification, according to official state narratives. This example (Fig. 11) highlights the juxtaposition of the historical narratives with postconflict discourse and suggests that these members of the younger generation seek to amend this in their vision for the future of the state. This is a primary function of youth subcultures: "to express and resolve, albeit 'magically,' the contradictions which remain hidden or unresolved in the parent culture" (Cohen 1972: 23). The function of youth subcultures to highlight and resolve such contradictions, combined with street art's function of social protest, provides the Dili artists with an optimal platform for addressing the many grievances that have arisen from their specific socio-political situation. Parkinson affirms, "It's a scene that keeps re-asserting itself as a marker of identity and continues to splash positive representations and messages around the country that critique, conflict and absolutely collide with the politics of the day" (Parkinson 
cited in Storey 2013).

Not only does this example demonstrate the desire of the street artists to resolve the contradictions of the parent culture, but it is indicative of the fact that national identity construction in Timor-Leste is far from over. By moving the focus of national narratives from the struggle, in which the younger generation's participation is largely overlooked, the artists open up the possibility of constructing an East Timorese national identity that is more inclusive. A future-oriented perspective which advocates peace and actively moves on from a history of funu suggests that these members of the younger generation have ideas about a national identity that differ significantly from that of their fellow East Timorese. If we recall the fact that young people constitute the majority of the population of Timor-Leste, the value and importance of their views on national identity in the on-going nation-building project cannot be overlooked. In attempts to publicly express and identify themselves, street art in Timor-Leste is a practical tool for those young East Timorese who might not otherwise be heard, both within established norms and in critiques of the dominant culture over the future of the nation.

\section{Conclusion}

As a product of youth subcultures, street art can provide insight into the values, attitudes and identities of younger generations who wish to contest the dominant culture of their societies. In Timor-Leste, the importance of its communicative role is further expounded by the socio-political situation of the Geração Foun in the early years of independence. By utilising street art as a platform for expression, East Timorese street artists have been able to both identify with their parent culture and challenge its limitations. The focus on text in "pieces" of graffiti have demonstrated the ways in which language choices reflect this tension, through the employment of the lingua-franca Tetun and the more unfamiliar Portuguese, primarily associated with the older generation.

The messages emitted through the examples of street art analysed here are positive: they demonstrate a desire to overcome the existing generation gap and communicate with the Generation of '75, but not without underlining its shortcomings. Moreover, they outline a vision for the future of the nation-state that is founded on peace, stability and unity. In order to legitimately participate in the nation-building project and realise these ideas, the artists (as members of the younger generation) identify with and utilise aspects of the dominant parent culture as key sources of power and identity. In terms of exogenous language choices, the incorporation of Portuguese language into their work is an explicit way in which the street artists demonstrate this identification, and thus present a more 'credible' viewpoint in the eyes of the older generation. By closely examining the content of street art, it is possible to better understand the situation of these members of the Geração Foun with regards to nation-building and national identity construction. In light of the significant under-representation of the younger generation in national politics, this presents a pressing issue which requires attention and a field of research that can be developed further. 


\section{References}

Anreus, Alejandro, Leonard Folgarait, and Robin Adèle Greeley (eds.) 2012. Mexican Muralism: a critical history. Berkeley: University of California Press.

Arnold, Matthew B. 2009. "Who is My Friend, Who is My Enemy"? Youth and Statebuilding in Timor-Leste.' International Peacekeeping. 16 (3): 379-392.

Arte Moris, http://artemoris.org.

Bennett, Andy. 1999. 'Subcultures or Neo-tribes? Rethinking the Relationship between Youth, Style and Musical Taste.' Sociology. 33 (3): 599-617.

Bexley, Angie. 2007. 'The Geração Foun, Talitakum and Indonesia: media and memory politics in Timor Leste.' Review of Indonesian and Malaysian Affairs. 41 (1): 71-90.

Bexley, Angie. 2011. 'Timor's Youth - from supermi to sojourns.' Asian Currents: 7-9.

Borgerhoff, Andre. 2006. 'The Double Task: Nation- and State-Building in Timor-Leste.' European journal of East Asian studies. 5(1): 101-130.

Clarke, John, Stuart Hall, Tony Jefferson and Brian Roberts. 1976. 'Subcultures, Cultures and Class: A Theoretical overview.' In Stuart Hall and Tony Jefferson (eds.). Resistance Through Rituals: Youth Subcultures in post-war Britain. London: Centre for Contemporary Cultural Studies: 9-74.

Clarke, Michael. 1974. 'On the concept of "Subculture.” The British Journal of Sociology. 25 (4): 428-441.

Cohen, Phil. 1972. 'Sub-cultural Conflict and Working Class Community.' Working Papers in Cultural Studies 2. University of Birmingham: 5-51.

Debies-Carl, Jeffrey S. 2013. 'Are the kids alright? A critique and agenda for taking youth cultures seriously.' Social Science Information. 52 (1): 110-133.

Democratic Republic of Timor-Leste Government. 2004. 'The Standard Orthography of the Tetun Language: Government Decree No. 1/2004 of 14 April 2004.' http://www.jornal. gov.t1/lawsTL/RDTL-Law/RDTL-Gov-Decrees/Gov-Decree-2004-01.pdf

Du, Wei. 2013. 'Timor Leste rethinks education for younger generation.' $11^{\text {th }}$ October. Channel News Asia (CNA). http://www.channelnewsasia.com/news/asiapacific/timor-leste-rethinks/844334.html.

Feixas, Carles, and Jordi Nofre. 2012. 'Youth Cultures.' Sociopedia.isa: 1-16.

Ferrell, Jeff. 1993. Crimes of Style: Urban Graffiti and the Politics of Criminality. New York: Garland Publishing.

Ferrell, Jeff. 1995. 'Urban Graffiti: Crime, Control and Resistance.' Youth and Society. 27 (1): 73-92.

Fox, James and Dionísio Babo Soares (eds.).2000. Out of the Ashes:Destruction and Reconstruction of East Timor. Adelaide: Crawford House Publishing.

Gadsby, Jane M. 1995. Looking at the Writing on the Wall: A Critical Review and Taxonomy of Graffiti Texts. http://www.hiphop-network.com/articles/graffitiarticles/criticaltaxonomyofgraff.asp.

Giller, Sarah. 1997. 'Graffiti: Inscribing Transgression on the Urban Landscape', Artcrime. http://www.graffiti.org/faq/giller.html.

Gómez, Marisa A.1992. 'The Writing on Our Walls: Finding Solutions through Distinguishing Graffiti Art from Graffiti Vandalism.' University of Michigan Journal for Law Reform. (26): 636-707.

Grin, François and Will Kymlicka. 2003. 'Assessing the politics of diversity in transition countries.' In Farimah Daftary and François Grin (eds.). Nation-building, Ethnicity and Language Politics in Transition Countries. Budapest: Open Society Institute: 1-27. 
Hebdige, Dick. 1979. Subculture: The Meaning of Style. London: Routledge.

Hull, Geoffrey. 2000. East Timor: Identity, Language and Educational Policy, English translation of address to the CNRT National Congress 25 August.

Hull, Geoffrey. 1999. Tetun Language Manual for East Timor. Sebastião Aparício da Silver Project.

International Crisis Group. 2011. Timor-Leste's Veterans: An Unfinished Struggle? Dili \& Brussels: International Crisis Group: 1-20.

Jarman, Neil. 1998. 'Painting Landscapes: The Place of Murals in the Symbolic Construction of Urban Space.' http://www.cain.ulst.ac.uk/bibdbs/murals/jarman.htm\#chap5.

Jenkins, Chaka. 1995. 'As the Sun Sets, we Rise: the Life and Times of a Graffiti Artist.' Public Art Review. Spring/Summer: 33-35.

Jolliffe, Jill. March 2011. 'Postcolonial Blues: East Timor's Lost Generation.' The Monthly: Australian politics, society and culture, March 2011. http://www.themonthly.com.au/issue/2011/march/1301812693/jill-jolliffe/postcolonial-blues.

Jørgensen, J. Normann. 2008. 'Urban Wall Languaging.' International Journal of Multilingualism. 5 (3): 237-252.

Kingsbury, Damien. 2010. 'National identity in Timor-Leste: challenges and opportunities.' South East Asia Research. 18 (1): 133-159.

Leach, Michael. 2003. "Privileged Ties:” Young People Debating Language, Heritage and National Identity in East Timor.' Portuguese Studies Review. 11 (1): 137-50.

Leach, Michael. 2006. "East Timorese history after independence." History workshop journal. 61 (1): 222-237.

Leach, Michael. 2008. "Surveying East Timorese tertiary student attitudes to national identity: 2002-2007.” South East Asia Research. 16 (3): 405-431.

Lisle, Debbie. 2006. 'Local Symbols, Global Networks: Rereading the Murals of Belfast.' Alternatives. (31): 27-52.

Macdonald, Nancy. 2001. The Graffiti Subculture: Youth, Masculinity and Identity in London and New York. New York: Palgrave Macmillan.

Menis, Anne. 2002. 'Towards an understanding of graffiti discourse.' Monash University Linguistic Papers. 2 (2): 43-54.

Obeng, Samuel Gyasi. 2000. 'Doing politics on walls and doors: A sociolinguistic analysis of graffiti in Legon (Ghana).' Multilingua. 19(4): 337-365.

Oxford English Dictionary (OED). http://oxforddictionaries.com.

Parkinson, Chris. Peace of Wall: Street Art from East Timor Blogspot. http://peaceofwall.blogspot. co.uk.

Parkinson, Chris. 2010. Peace of Wall: Street Art from East Timor. Hardie Grant Books.

Rafferty, Pat. 1991. 'Discourse on Difference: Street Art / Graffiti Youth.' Visual Anthropology Review. 7 (2): 77-84.

Ramos Gonçalves, Marisa. 2012. 'A Língua Portuguesa e o conflito intergeracional em TimorLeste.'In R. Teixeira E Silva, Y. Qiarong, M. Espadinha \& A. Leal (eds.). III SIMELP: A formação de novas geraçôes de falantes de português no mundo. Universidade de Macau: 1-15.

Ramos Gonçalves, Marisa. 2012a. 'A Língua Portuguesa e o conflito intergeracional em TimorLeste.' in III SIMELP: A formação de novas gerações de falantes de português no mundo, ed. by R. Teixeira E Silva, Y. Qiarong, M. Espadinha \& A. Leal. Macau: Universidade de Macau: $1-15$.

--- 2013. 'Ideas of Human Rights in the Walls, Paintings and Graffiti of Timor-Leste.' P@x Online Bulletin (22): 9-11. 
--- 2012b. 'Para além do visível. Percepções de direitos humanos nos murais e graffiti de TimorLeste', in Peskiza foun kona ba / Novas investigações sobre / Nerw Research on / Penelitian Baru mengenai Timor-Leste, ed. by Michael Leach, Nuno Canas Mendes, Antero B. da Silva, Bob Boughton and Alarico da Costa Ximenes. Hawthorn: Swinburne Press: 74-81.

Rolston, Bill. 2003. 'Changing the Political Landscape: Murals and Transition in Northern Ireland.' Irish Studies Review. 11 (1): 3-16.

Scambary, James. 2009. 'Anatomy of a conflict: the 2006-2007 communal violence in East Timor.' Conflict, Security Eं Development. 9 (2): 265-288.

Sieber, Tim, Graça Índias Cordeiro and Lígia Ferro. 2012. 'The Neighbourhood Strikes Back: Community Murals by Youth in Boston's Communities of Color.' City E' Society. 24 (3): 263-280.

Simião, Daniel Schroeter. 2005. 'O Feiticeiro Desencantado: gênero, justiça ea invenção da violência doméstica em Timor-Leste.' Anuário Antropológico. Rio de Janeiro: Tempo Brasileiro: 127-154.

Snellinger, Amanda. 2009. 'Yuba, Hanro Pusta: Youth and Generational Politics in Nepali Political Culture.' Studies in Nepali History and Society. 14 (1): 39-66.

Soares, Anthony. 2009. "National Identity and National Unity in Contemporary East-Timorese Literature.” Portuguese Studies. 25 (1): 80-101.

Storey, Thomas. 2013. 'Expressing the Legacy of Conflict: East Timorese Street Art.' The Culture Trip: East Timor. http://theculturetrip.com/asia/east-timor/articles/expressingthe-legacy-of-conflict-east-timorese-street-art.

Taylor-Leech, Kerry. 2012. "Language choice as an index of identity: linguistic landscape in Dili, Timor-Leste." International Journal of Multilingualism. 9 (1): 15-34.

Taylor-Leech, Kerry. 2009. 'The Language Situation in Timor-Leste.' Current Issues in Language Planning. 10 (1): 1-68.

Thomaz, Luis Filipe F.R. 'The Formation of Tetun-Praça, Vehicular Language of East Timor.' In Nigel Phillips and Anwar Khaidir (eds.). Papers on Indonesian Languages and Literatures. London: Indonesian Etymological Project: 54-83.

Traube, Elizabeth. 2007. 'Unpaid Wages: Local Narratives and the Imagination of the Nation.' The Asia Pacific Journal of Anthropology. (8): 9-25.

United Nations Development Programme (UNDP). 2011. Timor-Leste Human Development Report 2011: Managing Natural Resources for Human Development. UNDP: 1-158. 